\title{
Pengukuran Faktor yang Berpengaruh terhadap Kualitas Hidup Penderita HIV/AIDS pada Ibu Rumah Tangga
}

\author{
${ }^{1}$ S. Patimah*, \\ ${ }^{1}$ Program Studi Diploma III Kebidanan, STIKES Citra Delima Bangka Belitung \\ Email : tijanfatimah@gmail.com
}

\section{Kata kunci : \\ Promosi kesehatan, \\ lingkungan sosial, \\ peran petugas \\ kesehatan, \\ peran suami, \\ kualitas hidup. \\ Keywords : \\ Health promotion, social environment, health officer role, husband role, quality of life}

\section{Info Artikel:}

Tanggal dikirim:

30 Mei 2020

\section{Tanggal direvisi:}

14 Juni 2020

\section{Tanggal diterima :} 29 Juni 2020

DOI Artikel:

10.33862/citradelima. v4i1.105

Halaman: 52 - 65

\begin{abstract}
Abstrak
Kualitas hidup merupakan keadaan dimana seseorang mendapatkan kepuasan dan kenikmatan dalam kehidupan sehari-hari. Kualitas hidup tersebut menyangkut kesehatan fisik dan kesehatan mental yang berarti jika seseorang sehat secara fisik dan mental maka orang tersebut akan mencapai kepuasan dalam hidupnya. Tujuan dari penelitian ini untuk mengetahui pengaruh langsung dan tidak langsung promosi kesehatan lingkungan sosial, peran petugas kesehatan dan peran suami terhadap kualitas hidup penderita HIV/AIDS pada ibu rumah tangga di Yayasan Pelita Ilmu tahun 2017. Penelitian ini menggunakan metode cross sectional dengan sampel sebanyak 70 responden. Metode analisis yang digunakan adalah Structural Equation Model (SEM) menggunakan Smart PLS2.0 dan SPSS 18. Hasil penelitian ini menunjukkan pengaruh langsung dan tidak langsung antara variabel promosi kesehatan, lingkungan sosial, peran petugas kesehatan dan peran suami, terhadap kualitas hidup penderita HIV/AIDS pada ibu rumah tangga sebesar $76,8 \%$. Variabel kualitas hidup dipengaruhi langsung oleh beberapa variabel, diantaranya promosi kesehatan $(12,14 \%)$, lingkungan sosial $(23,83 \%)$, peran petugas kesehatan $(30,31 \%)$, dan peran suami sebesar (10,50\%). Pengaruh tidak langsung sebesar 1,51\%. Petugas kesehatan di Yayasan Pelita Ilmu sehingga lebih meningkatkan pelayanan pendidikan serta pendekatan kepada penderita HIV/AIDS sehingga akan meningkatkan kualitas hidup yang lebih baik.
\end{abstract}

\section{Measurement of Factors that Influence the Quality of Life of People with HIV/AIDS to Houswives}

\begin{abstract}
Quality of life is a state where one gets satisfaction and enjoyment in everyday life. Quality of life is related to physical health and mental health which means if a person healthy physically and mentally then the person will achieve satisfaction in his life. The purpose of this research is to know the direct and indirect influence of health promotion of social environment, the role of health officer and the role of husband to the quality of life of HIV / AIDS sufferers in housewife at Yayasan Pelita Ilmu in 2017. This research uses cross sectional method with 70 samples respondents. Analytical methods used are Structural Equation Model (SEM) using Smart PLS2.0 and SPSS 18. The results of this study indicate the direct and indirect influence between health promotion variables, social environment, the role of health workers and husband role, to the quality of life of HIV / AIDS in housewives by $76.8 \%$. The quality of life variable is directly influenced by several variables, including health promotion $(12,14 \%)$, social environment $(23,83 \%)$, health officer role $(30,31 \%)$, and husband role $(10,50 \%)$. Indirect effect of $1.51 \%$. Pelita Ilmu Foundation counseling officers to provide support to HIV / AIDS sufferers in housewives by increasing the role of health workers to create HIV / AIDS sufferers in housewives with high quality of life.
\end{abstract}




\section{PENDAHULUAN}

Penyakit Human Immunodeficiency Virus (HIV) merupakan penyakit infeksi penyebab kematian peringkat atas dengan angka kematian (mortalitas) dan angka kejadian penyakit (morbiditas) yang tinggi serta membutuhkan diagnosis dan terapi yang cukup lama. HIV merupakan virus yang menyerang sel darah putih (limfosit) di dalam tubuh yang mengakibatkan turunnya kekebalan tubuh manusia sehingga menyebabkan Aqciured Immunodeficiency Syndrome (AIDS) (Kemenkes RI, 2015)

Salah satu fenomena HIV-AIDS di Jakarta Selatan adalah dari 3383 kasus kumulatif HIV-AIDS di Jakarta Selatan, 445 kasus terdeteksi pada ibu rumah tangga, sedangkan pada pekerja seks komersial (PSK) terdeteksi 274 kasus (Yayasan Pelita Ilmu Jakarta, 2016).

Dari fakta di atas, semakin jelas terlihat HIVAIDS sudah tidak hanya mengenai orang-orang dengan perilaku seks bebas atau pemakaian jarum suntik. Walaupun demikian, terlepas dari penyebab tertularnya, orang dengan HIV/AIDS (ODHA) seringkali mendapat stigma dan diskriminasi dari masyarakat umum (Yayasan Pelita Ilmu Jakarta, 2016) Isu yang berkembang dan beredar di masyarakat adalah HIVAIDS terdapat pada orang-orang yang berzinah, melacur, seks bebas, jajan, homoseksual dan selalu dikaitkan dengan isu moral, iman dan ketakwaan, padahal kenyataannya tidak selalu begitu dan sudah menyebar ke ibu rumah tangga (Dewi, 2016).

Ibu rumah tangga sendiri menganggap HIV adalah aib dan karma yang menimbulkan ketakutan untuk menceritakan kondisinya kepada orang lain. Selain itu, cap dari masyarakat membuat ODHA merasa tidak memiliki tempat untuk berbagi perasaannya dengan orang luar karena tidak ada orang yang mau menerima kondisi mereka (Rulianthina, 2008).

Di salah satu desa di kecamatan Tanjung Morawa menunjukkan bahwa stigma terhadap ibu rumah tangga dengan HIV berpengaruh terhadap penerimaan masyarakat atas keberadaan ODHA sehingga akan berakibat pada kualitas hidup baik atau akan sebaliknya (Siregar, 2012).

Orang dengan HIV/AIDS atau ODHA akan menagalami banyak hambatan secara fisik, sosial maupun psikologis. ODHA akan mengalami penurunan kemampuan fisik yang disebabkan oleh virus HIV positif akan lebih mudah untuk terserang berbagai penyakit yang akan memberikan pengaruh terhadap aktivitasnya sehari-hari (Aritonang, 2014).

Stigma dan diskriminasi menciptakan suatu tekanan fisik maupun psikologis penderita HIV positif. Pengalaman individu yang terinfeksi HIV/AIDS serta pengaruh lingkungan yang negatif akan membangkitkan berbagai perasaan dan reaksi stress, frustasi, kecemasan, kemarahan dan penyangkalan, rasa malu, berduka dan ketidakpastian dengan adaptasi terhadap kondisi dirinya (Widyaningtyas, 2009).

Perubahan yang terjadi dalam diri ODHA membuat mereka memiliki persepsi negatif tentang dirinya sendiri. ODHA cenderung menunjukkan bentukbentuk reaksi sikap dan tingkah laku yang salah. Hal ini disebabkan oleh ketidakmampuan ODHA menerima kenyataan dengan kondisi baik dari dalam dirinya maupun dari lingkungan sekitar ia berada (Hena, 2015).

Pada kenyataannya tidak semua individu dapat segera bangkit dari keterpurukan yang dialaminya, terutama baik mereka dengan status HIV/AIDS karena beratnya beban yang diterima baik dari luar seperti dari lingkungan mereka, maupun dari dalam diri mereka sendiri sehingga berdampak pada kualitas hidup ibu rumah tangga dengan HIV/AIDS. Mereka yang mampu seketika bangkit memiliki syarat untuk menyadari kemampuannya sebagai suatu "anugrah" tersendiri. Hal tersebut bearrti pengalaman yang telah dilaluinya mampu membentuk sedemikian rupa menjadi individu yang kuat terhadap penderita. Kualitas hidup merupakan keadaan dimana seseorang mendapatkan kepuasan dan kenikmatan dalam kehidupan sehari-hari. Kualitas hidup

http://jurnalilmiah.stikescitradelima.ac.id/index.php/JI Vol.4,No.1, Juli 2020 
tersebut menyangkut kesehatan fisik dan kesehatan mental yang berarti jika seseorang sehat secara fisik dan mental maka orang tersebut akan mencapai kepuasan dalam hidupnya (Nazir, 2010)

Berdasarkan hasil studi pendahuluan yang dilakukan oleh peneliti terhadap 10 orang Penderita HIV/AIDS pada ibu rumah tangga di Yayasan Pelita Ilmu ditemukan sebanyak $70 \%$ penderita HIV/AIDS pada ibu rumah tangga mempunyai Kualitas Hidup yang masih rendah dan sisanya 30\% mempunyai Kualitas Hidup baik. Sebanyak $60 \%$ mempunyai promosi kesehatan baik dan sisanya $40 \%$ mempunyai Promosi Kesehatanrendah. 60\% mempunyai Lingkungan Sosial rendah dan $40 \%$ mempunyai Lingkungan Sosial yang baik.70\% Peran Tenaga Kesehatan yang tinggi dan 30 $\%$ Peran Tenaga Kesehatan rendah. 40\% dari ODHA memiliki Peran suami yang tinggi dan 60\% lainnya memiliki Peran suami yang rendah pada penderota HIV/AIDS pada Ibu Rumah Tangga.

Tujuan dari penelitian ini adalah untuk mengetahui pengaruh langsung dan tidak langsung serta besarannya antara promosi kesehatan, lingkungan sosial peran petugas kesehatan dan peran suami terhadap kualitas hidup penderita HIV/AIDS pada ibu rumah tanggadi Yayasan Pelita Ilmu

\section{METODE}

Penelitian yang dilakukan menggunakan metode penelitian analitik dengan pendekatan cross sectional yang bertujuan untuk mengetahui pengaruh langsung dan tidak langsung anatara promosi kesehatan, lingkungan sosial peran petugas kesehatan dan peran suami terhadap kualitas hidup penderita HIV/AIDS pada ibu rumah tangga pada bulan November 2016 di Yayasan Pelita Ilmu Tahun Jakarta.

Populasi dalam penelitian ini adalah seluruh penderita HIV/AIDS pada ibu rumah tangga yang berada di Yayasan Pelita Ilmu. Teknik analisis data yang digunakan untuk membahas permasalahan dalam penelitian ini adalah Structural Equation Model (SEM).

SEM adalah sebuah model statistik yang memberikan perkiraan perhitungan dari kekuatan hubungan hipotesis diantara variabel dalam sebuah model teoritis, baik secara langsung atau melalui variabel antara (intervening or mediating variables) (Mustafa \& Tony, 2012).

Menentukan jumlah sampel dalam analisis SEM adalah 5-10 $\mathrm{x}$ jumlah indikator dalam penelitian.10Jumlah indikator dalam penenelitian ini adalah 12 x 5-10 = 60-120 jadi jumlah sampel dalam penelitian ini antara 60120 responden. Dalam penelitian ini jumlah sampel yang digunakan adalah 70 penderita HIV/AIDS pada Ibu Rumah Tangga.

Kriteria inklusi dan ekslusi sampel dalam penelitian ini adalah: (1) kriteria inklusi yaitu: ibu rumah tangga dengan HIV/AIDS di Yayasan Pelita Ilmu, bersedia menjadi responden, ibu rumah tangga dengan HIV/AIDS yang memiliki kemampuan komunikasi dan membaca yang baik. (2)

Kriteria eksklusi adalah menghilangkan atau mengeluarkan subjek yang memenuhi kriteria inklusi dari penelitian. Kriteria eksklusi pada penelitian ini adalah ibu rumah tangga dengan HIV/AIDS yang sesuatu hal berhalangan sehingga tidak dapat menjadi responden. Untuk memperoleh data yang diperlukan, maka dalam penelitian ini menggunakan cara pengumpulan data melalui kuesioner.

Intrumen dalam penelitian ini menggunakan skala semantic differensial. Skala ini digunakan untuk mengukur sikap/karakteristik tertentu yang dipunyai oleh seseorang. Skala tersebut tersusun dalam satu garis kontinum yang jawab "sangat positifnya" terletak di bagian kanan garis dan jawaban yang "sangat negatif" terletak dibagian kiri garis, atau sebaliknya (Nursalam, 2011).

Uji coba instrumen pada penelitian ini menggunakan uji coba terpakai. Angket yang telah dibuat

http://jurnalilmiah.stikescitradelima.ac.id/index.php/JI Vol.4,No.1, Juli 2020 
langsung diuji cobakan kepada sampel penelitian, dengan kata lain yaitu melaksanakan uji coba sekaligus pengumpulan data. Dari perolehan data tersebut langsung dijadikan dasar untuk mengukur validitas dan reliabilitasnya. Teknik uji coba terpakai ini dilakukan karena pertimbangan penghematan dan efisiensi waktu (Ghozali, 2008).

Evaluasi dengan loading factor dilakukan untuk menilai signifikasi konstruk laten dengan dengan konstruknya, loading factor di atas 0.70 sangat direkomendasikan namun demikian loading factor 0.50 0.60 masih dapat ditolerir sepanjang model masih dalam tahap pengembangan.

Selain evaluasi dengan loading factor untuk melihat discriminant validity adalah dengan melihat nilai square root of averange variance extracted (AVE). Konstruk dengan validitas yang baik dipersyaratkan nilai AVE harus di atas 0.50. Uji reliabilitas dilakukan dengan melihat nilai Composite Reliability dan Cronbach Alpha, nilai Composite Reliability dan Cronbach Alpha untuk semua konstruk Exogen, Endogen dan Moderating semua sangat reliabel jika nilainya di atas 0.70 (Ghozali, 2008).

Data penelitian ini disajikan dalam bentuk (1) penyajian komposisi dan frekuensi dari sampel. (2) penyajian analisa SEM Data penyajian analisa SEM dari pengolahan data output yang menggunakan bantuan SPSS 18 dan SmartPLS 2.0, disajikan dalam diagram, tabel dan lain-lain.

\section{HASIL DAN PEMBAHASAN}

\section{Hasil}

Deskripsi jawaban 70 responden tentang variabel kualitas hidup sebagian besar berada pada rentang aktual 45-49 (26\%), pada variabel promosi kesehatansebagian besar berada pada rentang aktual 62-68 (26\%), pada variabel lingkungan sosial sebagian besar berada pada rentang aktual 62-68 (27\%), pada variabel peran petugas kesehatan sebagian besar berada pada rentang aktual 45-
49 (24\%), pada variabel peran suami sebagian besar berada pada rentang aktual 41-47 (26\%).

Pada variabel Kualitas Hidup, kisaran jawaban responden antara 40-74 mendekati kisaran teoritisnya (15-75) dengan nilai rata-rata 50,50 dan standar deviasi 7,072. Pada variabel promosi kesehatan kisaran jawaban responden antara 27-75 mendekati kisaran teoritisnya pada nilai tertinggi (15-75) dengan nilai rata-rata 50,20 dan standar deviasi 6,210. Pada variabel lingkungan sosial, penilaian terhadap lingkungan sosial yang diberikan27-75 berada di tengah kisaran teoritisnya (115) dengan dengannilai rata-rata 54,00 dan standar deviasi 8,232. Pada variabel Peran tenaga kesehatan, penilaian terhadap peran tenaga kesehatanantara 40-74 mendekati kisaran teoritisnya (15-75) dengan nilai ratarata 52,50 dan standar deviasi 8.002. Pada variabel Peran suami, penilaian terhadap Peran suamiantara 27-75 mendekati kisaran teoritisnya (15-75) dengan nilai ratarata 50,40 dan standar deviasi 6,339.

Deskripsi jawaban responden pada variabel penelitian kualitas hidup dengan jumlah responden 70 , nilai jawaban responden minimum adalah 40 dan yang maksimum adalah 74 dengan mean 50,50 median 50 dan nilai mode adalah 48.Pada variabel penelitian promosi kesehatandengan jumlah responden 70 , nilai jawaban responden minimum adalah 27 dan yang maksimum adalah 75 dengan mean 50,20median 50 dan nilai mode adalah 48.Pada variabel lingkungan sosial dengan jumlah responden 70, nilai jawaban responden minimum adalah 27 dan yang maksimum adalah 75 dengan mean 54,00median 52 dan nilai mode adalah 52.Pada variabel peran petugas kesehatan dengan jumlah responden 70 , nilai jawaban responden minimum adalah 40 dan yang maksimum adalah 74 dengan mean 52,50median 50 dan nilai mode adalah 48. Pada variabel peran suami dengan jumlah responden 70, nilai jawaban responden minimum adalah 27 dan yang maksimum adalah 75 dengan mean 50,40median 50 dan nilai mode adalah 52.

http://jurnalilmiah.stikescitradelima.ac.id/index.php/JI Vol.4,No.1, Juli 2020 
Varibel kualitas hidup tidak berhubungan dengan karakteristik responden karena hasil uji chi square dengan taraf signifikansi 5\% semuanya lebih besar dari 0,05 . yaitu umur 0,666 , pekerjaan 0,429 , pendidikan 0,821. Varibel promosi kesehatan tidak berhubungan dengan karakteristik responden karena hasil uji chi square dengan taraf signifikansi 5\% semuanya lebih besar dari 0,05. yaitu umur 0,100, pekerjaan 0,900, pendidikan 0,925. Varibel lingkungan sosial tidak berhubungan dengan karakteristik responden karena hasil uji chi square dengantaraf signifikansi 5\% semuanya lebih besar dari 0,05. yaitu umur 0,188, pekerjaan 0,100 , pendidikan 0,300 . Varibel peran tenaga kesehatan tidak berhubungan dengan karakteristik responden karena hasil uji chi square dengan taraf signifikansi $5 \%$ semuanya lebih besar dari 0,05 . yaitu umur 0,628, pekerjaan 0,339, pendidikan 0,979.

Dari gambar 1 Indikator reflektif dinyatakan valid jika mempunyai Loading Factor di atas 0,5. Pada variabel promosi kesehatan sebesar 0,000. Pada variabel lingkungan sosial sebesar 0,591 memiliki tiga indikator yaitu hubunghan dengan keluarg, potensi pengaruh tentangga dan penyesuaian diri dengan teman sebaya. Variabel peran petugas kesehatan sebesar 0,734. Variabel peran suami sebesar 0,726 memiliki tiga indikator yaitu dukungan materi, pendampingan dan kepedulian. Dan variabel kualitas hidup sebesar 0,768 tidak memiliki indikator.

Pada variabel promosi kesehatan sebesar 0,000 memiliki tiga indikator yaitu penyuluhan penggunaan kondom sebesar 0,771, pembinaan forum peduli HIV/AIDS sebesar 0,966 dan pemberian konseling sebesar 0,848.Pada variabel lingkungan sosial sebesar 0,591 memiliki tiga indikator yaitu hubunghan dengan keluarg sebesar 0,995. Variabel peran petugas kesehatan sebesar 0,734 memiliki tiga indikator yaitu konselor sebesar 0,668, health monitoring sebesar 0,901dan innovator sebesar 0,897. Dan variabel kualitas hidup sebesar 1,000 .

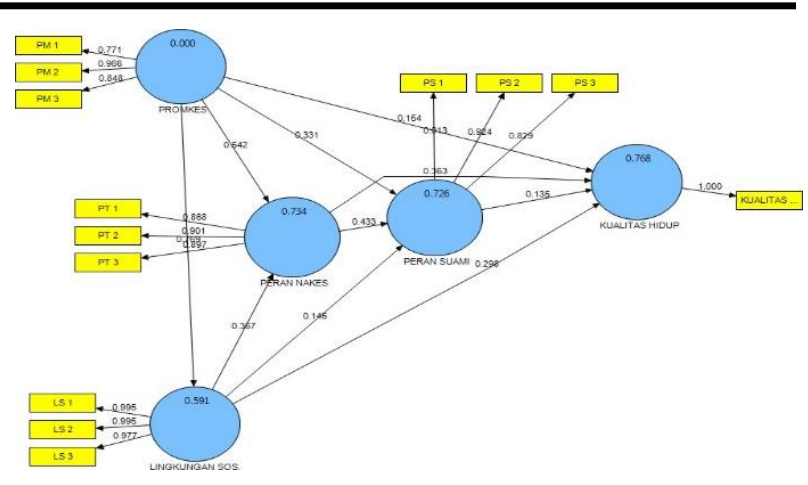

\section{Gambar 1 Output PLS (Loading Factor)}

Berdasarkan gambar I Loading factor kualitas hidup sebesar (1,000) yang lebih besar daripada loading faktor promosi kesehatan $(0,7900)$, lingkungan sosial $(0,801)$, peran petugas kesehatan $(0,834)$, dan peran suami $(0,776)$. Hal serupa juga tampak pada indikator-indikator lainnya.

Evaluasi evaluasi Average Variance Extracted (AVE) dinyatakan valid yaitu promosi kesehatan0,749 lingkungan sosial 0,978 peran petugas kesehatan 0,789 peran suami 0,791 dan kualitas hidup1,000.

Hasil pengukuran pada Cronbach's Alpha menyatakan bahwa semua konstruk dalam model yang dietimasi memenuhi syarat kosntruk yaitu pada variabel promosi kesehatan 0,827, lingkungan sosia 10,988 peran petugas kesehatan0,867, peran suami 0,867dan kualitas hidup sebesar 1,000. Dan pada nilai Composite Reliability variabel promosi kesehatan 0,898, lingkungan sosial sebesar 0,992, variabel peran petugas kesehatan sebesar 0,918, variabel peran suami sebesar 0,919 dan variabel kualitas hidup sebesar 1,000 .

Tabel 1. Evaluasi Nilai R-Square

\begin{tabular}{ll}
\hline \multicolumn{1}{c}{ Variable } & R-Square \\
\hline Kualitas Hidup & 0,767739 \\
\hline Promosi Kesehatan & \\
\hline Lingkungan Sosial & 0,591210 \\
\hline Peran Nakes & 0,733863 \\
\hline Peran Suami & 0,726490 \\
\hline
\end{tabular}

http://jurnalilmiah.stikescitradelima.ac.id/index.php/JI Vol.4,No.1, Juli 2020 
Berdasarkan tabel I dapat dilihat bahwa konstruk lingkungan sosial didapatkanangka sebesar 0,591 dapat diinterpretasikan bahwa variabilitas konstruk lingkungan sosial dapat dijelaskan oleh konstruk promosi kesehatan $59 \%$ dan sisanya $41 \%$ dipengaruhi oleh variabel lain yang tidak diteliti.

Pada variabel peran petugas kesehatan didapatkan angka sebesar 0,733dapat diinterpretasikan bahwa variabilitas konstruk stress dapat dijelaskan oleh

konstruk promosi kesehatan sebesar $73 \%$ dan sisanya $27 \%$ dipengaruhi oleh variabel lain yang tidak diteliti. Pada variabel peran suami didapatkan angka sebesar 0,726dapat diinterpretasikan bahwa variabilitas konstruk promosi kesehatan dapat dijelaskan oleh konstruk optimisme sebesar $72 \%$ dan sisanya $28 \%$ dipengaruhi oleh variabel lain yang tidak diteliti.

Pada variabel kualitas hidup didapatkan angka sebesar 0,767 dapat diinterpretasikan bahwa variabilitas konstruk kualitas hidup dapat dijelaskan oleh konstruk resiliensi sebesar $76 \%$ dan sisanya $24 \%$ dipengaruhi oleh variabel lain yang tidak diteliti.

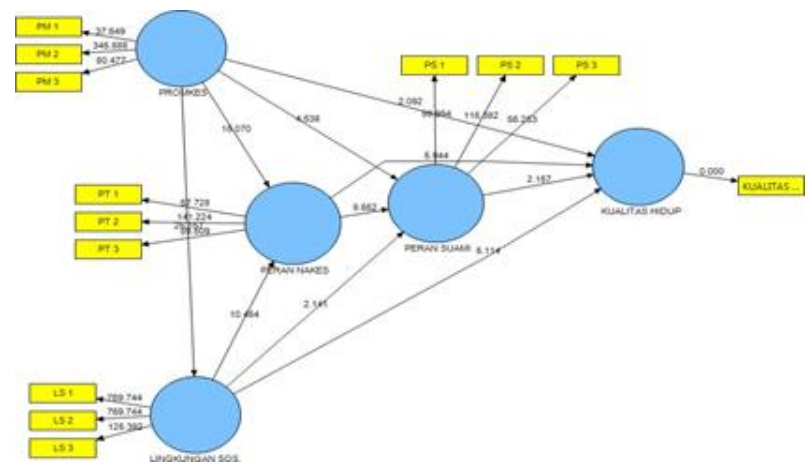

Gambar 2. Output PLS (T-Statistik)

Hasil pengukuran nilai Path Coefficient/Rho dan nilai T-statistik dapat dijelaskan bahwa hasil uji terhadap koefisien parameter antara variabel yang diteliti yaitu variabel promosi kesehatan terhadap kualitas hidup menunjukkan pengaruh positif dan signifikan yaitu 0,153dan nilai T-statistik sebesar 2,863. Variabel lingkungan sosial terhadap kualitas hidup menunjukkan pengaruh positif dan signifikan sebesar 0,297dan nilai Tstatistik sebesar 6,824.
Hasil pengukuran nilai Path Coefficient/Rho dan nilai T-statistik dapat dijelaskan bahwa hasil uji terhadap koefisien parameter antara variabel yang diteliti yaitu variabel promosi kesehatan terhadap kualitas hidup menunjukkan pengaruh positif dan signifikan yaitu 0,153dan nilai $\mathrm{T}$-statistik sebesar 2,863. Variabel lingkungan sosial terhadap kualitas hidup menunjukkan pengaruh positif dan signifikan sebesar 0,297dan nilai Tstatistik sebesar 6,824.

Variabel peran tenaga Kesehatan terhadap kualitas hidup berpengaruh positif dan signifikan sebesar 0,363dan nilai T-statistik sebesar 9,861. Variabel peran suami terhadap kualitas hidup berpengaruh positif dan signifikan sebesar 0,135dan nilai Tstatistik sebesar 5,942.Variabel promosi kesehatan terhadap peran suami berpengaruh positif dan signifikan sebesar 0,331 dan nilai T-statistik sebesar 5,097. Variabel lingkungan sosial terhadap peran suami berpengaruh positif dan signifikan sebesar 0,145dan nilai T-statistik 10,888. Variabel peran tenaga kesehatanterhadap peran suami berpengaruh positif dan signifikan sebesar 0,432dan Tstatistik 2,011.

Variabel promosi kesehatanterhadap peran tenaga kesehatan berpengaruh positif dan signifikan sebesar 0,541 dan T-statistik sebebsar 3,005.Variabel lingkungan sosial terhadap peran tenaga kesehatan berpengaruh positif dan signfikan sebesar 0,366dengan nilai $T$ statistik 3,858. Variabel promosi kesehatan terhadap lingkungan sosial berpengaruh positifdan siginifikan sebesar 0,768dan T-statistik 44,476.

http://jurnalilmiah.stikescitradelima.ac.id/index.php/JI

Vol.4,No.1, Juli 2020 


\begin{tabular}{cccccccc}
\hline Sumber & $\begin{array}{c}\boldsymbol{L} \boldsymbol{V} \\
\text { Correlation }\end{array}$ & $\begin{array}{c}\text { Direct } \\
\text { Path }\end{array}$ & $\begin{array}{c}\text { Indirect } \\
\text { Path }\end{array}$ & Total & $\begin{array}{c}\text { Direct } \\
(\boldsymbol{\%})\end{array}$ & $\begin{array}{c}\text { Indirect } \\
(\mathbf{\%})\end{array}$ & Total (\%) \\
\hline Promosi Kesehatan (PM) & 0,790084 & 0,153704 & 3,7726 & 3,9263 & $12,14 \%$ & $1,154 \%$ & $13,30 \%$ \\
\hline Lingkungan Sosial (LS) & 0,8005 & 0,297638 & 1,7126 & 2,0102 & $23,83 \%$ & $0,359 \%$ & $24,185 \%$ \\
\hline Peran Nakes (PT) & 0,834067 & 0,363378 & 0,6356 & 0,9990 & $30,31 \%$ & $0,0013 \%$ & $30,309 \%$ \\
\hline Peran suami (PS) & 0,775787 & 0,135293 & - & 0,1353 & $10,50 \%$ & $0,000 \%$ & $10,496 \%$ \\
\hline \multicolumn{1}{c}{ Total } & & & & & $\mathbf{7 6 . 8 \%}$ & $\mathbf{1 . 5 1 \%}$ & $\mathbf{7 8 . 3 \%}$ \\
\hline
\end{tabular}

Berdasarkan tabel 2 diketahui bahwa pengaruh langsung lebih besar dibandingkan pengaruh tidak langsung. Besarnya pengaruh langsung (direct effect) yaitu $76,8 \%$. Promosi kesehatan terhadap kualitas hidup menunjukkan terdapat pengaruh langsung sebesar 12,14\%, Lingkungan sosial terhadap kualitas hidup menujukan terdapat pengaruh langsung sebesar 23,83\%, Peran tenaga kesehatan terhadap Kualitas Hidup menujukan terdapat pengaruh langsung sebesar 30,31\% dan Peran suami terhadap kualitas hidup menujukan terdapat pengaruh langsung sebesar 10,5\%.

Sedangkan untuk pengaruh tidak langsung antara Promosi kesehatan terhadap kualitas hidup sebesar $1,154 \%$, pengaruh tidak langsung antara lingkungan sosial terhadap kualitas hidup sebesar $0,36 \%$, pengaruh tidak langsung antara lingkungan sosial terhadap kualitas hidup sebesar 0,00013\% sedangkan untuk pengaruh tidak langsung antara Peran suami terhadap Kualitas Hidup sebesar 0,00\%.

$$
\eta 2=D_{1} \beta 1+\xi \gamma 2+\varsigma^{2}
$$

Peran tenaga kesehatan $=14,7$ Promosi kesehatan $+17,1$ lingkungan sosial $+68,2$ faktor lain. Peran tenaga kesehatan dipengaruhi oleh faktor Promosi kesehatan sebesar $14.7 \%$, faktor lingkungan sosial sebesar $17.5 \%$ dan sisanya $68.2 \%$ dipengaruhi oleh faktor lain yang tidak diteliti dalam penelitian ini.

$$
\boldsymbol{\eta} \mathbf{3}=\mathrm{D}_{1} \beta 2+\mathrm{D}_{2} \beta 4+\xi \gamma 4+\varsigma 3
$$

Peran suami $=26.6$ Promosi kesehatan +42.8 lingkungan sosial +4.3 Peran tenaga kesehatan +26.3 faktor lain. Peran suami dipengaruhi oleh faktor Promosi kesehatan sebesar 26.6\%, faktor lingkungan sosial sebesar $42.8 \%$, faktor Peran tenaga kesehatan sebesar $4.3 \%$ dan sisanya $26.3 \%$ dipengaruhi oleh faktor lain yang tidak diteliti dalam penelitian ini.

$$
\mathbf{\eta} \mathbf{4}=\mathrm{D}_{1} \beta 3+\mathrm{D}_{2} \beta 5+\mathrm{D}_{3} \beta 6+\xi \gamma 3+\varsigma 4
$$

Kualitas Hidup $=11.22$ Promosi kesehatan + 22.89 lingkungan sosial +26.76 Peran tenaga kesehatan + 32.48 Peran suami + 8.4 faktor lain. Kualitas Hidup dipengaruhi oleh faktor Promosi kesehatan sebesar $15.83 \%$, faktor lingkungan sosial sebesar $7.94 \%$, faktor lingkungan sosial sebesar $35.3 \%$, faktor Peran suami sebesar $24.5 \%$ dan sisanya $14.6 \%$ dipengaruhi oleh faktor lain yang tidak diteliti dalam penelitian ini.

\section{Pembahasan}

\section{Pengaruh Langsung Promosi kesehatan terhadap Kualitas hidup.}

Terdapat pengaruh langsung sebesar $12.14 \%$, sedangkan untuk pengaruh tidak langsung promosi kesehatan terhadap kualitas hidup penderita HIV/AIDS pada Ibu Rumah Tangga di Yayasan Pelita Ilmu Jakarta Selatan melalui lingkungan sosial dan peran tenaga kesehatan 1.15\%. Nilai T-Statistik sebesar 3.036 dan signifikan pada $\alpha=5 \%$. Nilai TStatistic tersebut berada jauh diatas nilai kritis $(1,96)$.

Berdasarkan hasil uji tersebut dapat dijelaskan bahwa pengaruh langsung promosi kesehatan lebih besar nilainya dibandingkan dengan pengaruh tidak langsung dan signifikan ada pengaruh yang positif dari kedua variabel tersebut.Nilai T-statitik menunjukan, bahwa ada

http://jurnalilmiah.stikescitradelima.ac.id/index.php/JI Vol.4,No.1, Juli 2020 
pengaruh langsung dan tidak langsung antara promosi kesehatan terhadap kualitas Hidup Penderita HIV/AIDS pada ibu rumah Tangga di Yayasan Pelita Ilmu Jakarta Selatan tahun 2017.

Berdasarkan hasil uji tersebut dapat dijelaskan bahwa pengaruh langsung Promosi kesehatan lebih besar nilainya dibandingkan dengan pengaruh tidak langsung dan signifikan ada pengaruh yang positif dari kedua variabel tersebut. Nilai T-statistik menunjukan, bahwa ada pengaruh langsung dan tidak langsung antara promosi kesehatan terhadap kualitas hidup penderita HIV/AIDS pada ibu rumah tangga di Yayasan Pelita Ilmu Jakarta Selatan tahun 2017.

Hasil penelitian menunjukkan, terdapat pengaruh yang positif dari promosi kesehatan terhadap kualitas hidup penderita HIV/AIDS pada Ibu rumah tangga di Yayasan Pelita Ilmu Jakarta Selatan. Sehingga apabila Promosi kesehatan ditingkatkan maka dapat meningkatkan kualitas hidup.

Kualitas hidup penderita HIV/AIDS pada ibu rumah tangga di Yayasan Pelita Ilmu Jakarta Selatansecara langsung maupun secara tidak langsung melalui lingkungan sosial dan peran tenaga kesehatan, begitupun sebaliknya apabila promosi kesehatan menurun, maka dapat menurunkan kualitas hidup penderita HIV/AIDS pada ibu rumah tangga di Yayasan Pelita Ilmu Jakarta Selatansecara langsung dan tidak langsung (Saptari, 2013).

Menurut asumsi penelitian bahwa strategi promosi kesehatan tidak dapat lepas dari media karena melalui media, pesan pesan yang disampaikan dapat lebih menarik dan dipahami, sehingga sasaran dapat mempelajari pesan tersebut sampai memutuskan untuk mengadopsi perilaku yang positif ke arah yang semula tidak berperilaku hidup tidak sehat dengan menjadi hidup sehat sehingga dapat berpengaruh langsung pada peningkatan kualitas Hidup
Pengaruh Tidak Langsung Promosi Kesehatan terhadap Kualitas Hidup Melalui Lingkungan Sosial, Peran Tenaga Kesehatan dan Peran Suami.

Promosi kesehatan terhadap kualitas hidup penderita HIV/AIDS pada Ibu Rumah Tangga di Yayasan Pelita Ilmu Jakarta Selatan melalui lingkungan sosial, peran tenaga kesehatan dan peran suami sebesar1.15\%. Nilai T-Statistic sebesar 3.036 dan signifikan pada $\alpha=5 \%$. Nilai T-Statistik tersebut berada jauh diatas nilai kritis $(1,96)$.

Pengaruh tidak langsung promosi kesehatan terhadap kualitas hidup penderita HIV/AIDS pada ibu iumah tangga di Yayasan Pelita Ilmu Jakarta Selatan dilalui oleh variabel lingkungan sosial sebesar 0,503\%, peran tenaga kesehatan sebesar $0.483 \%$ dan variabel peran suami sebesar $0,502 \%$. Hasil persentase pengaruh tidak langsung terhadap kualitas hidup penderita HIV/AIDS pada ibu rumah tangga di Yayasan Pelita Ilmu Jakarta Selatan lebih di dominasi oleh lingkungan sosial.

Promosi kesehatan mempengaruhi kualitas hidupPenderita HIV/AIDS melalui lingkungan sosial.Promosi kesehatan dan lingkungan sosial merupakan bagian yang tidak dapat dipisahkan dari kehidupan masyarakat (Saptari, 2013).

Secara tidak langsung lingkungan sosial membentuk pengalaman individu yang terinfeksi HIV/AIDS serta pengaruh lingkungan yang negatif akan membangkitkan berbagai perasaan dan rekasi stress, frustasi, kecemasan, kemarahan dan penyangkalan, rasa malu, berduka dan ketidakpastian dengan adaptasi terhadap kondisi dirinya (Siregar, 2012).

Promosi kesehatan mempengaruhi kualitas hidupPenderita HIV/AIDS melalui peran tenaga kesehatan yaitu ada keterkaitan pengaruh tidak langsung antara peran tenaga kesehatan dengan keberhasilan promosi kesehatan.

Tenaga kesehatan sebagai ujung tombak pelayanan kesehatan ibu rumah tangga dengan

http://jurnalilmiah.stikescitradelima.ac.id/index.php/JI Vol.4,No.1, Juli 2020 
HIV/AIDS, kelahiran dan pemeliharaan kesehatan ibu dan anak, memiliki peran cukup strategis dalam upaya menekan laju pertumbuhan penyakit HIVAIDS di antara kelompok masyarakat pengunjung Puskesmas dan Rumah Sakit terutama pada pelayanan KIA/KB (Saptari, 2013)

Kehidupan ibu rumah tangga dengan HIV/AIDS dengan infeksi HIV akan kelihatan berbeda apabila ia mendapat respon yang baik dari suaminya dibandingkan apabila mendapat respon negatif berupa penolakan dan diskriminasi dari keluarganya maupun orang terdekatnya. Sanggat penting bagi keluarga untuk memberikan dukungan, kasih sayang, perhatian dan sikap yang baik bagi ibu rumah tangga dengan HIV/AIDS khususnya perempuan.

Dukungan suami membuat ibu rumah tangga dengan HIV/AIDS sendiri bisa lebih mengatur hidupnya. ODHA biasanya akan cepat membaik, dengan kenyamanan di rumah dan juga dukungan dari teman terutama keluarga (Saptari, 2013).

\section{Pengaruh Langsung Lingkungan Sosial terhadap Kualitas Hidup.}

Pengaruh langsung dan besaran lingkungan sosialterhadapkualitas hidup penderita HIV/AIDS pada ibu rumah tangga di Yayasan Pelita Ilmu tahun 2017 adalah pengaruh antara lingkungan sosial dengan kualitas hidup penderita HIV/AIDS pada ibu rumah tangga juga menunjukan angka yang signifikan, yaitu dengan menggunakan taraf kepercayaan $95 \%$ pada kosntanta 1,96 dibandingkan dengan nilai di dapat yaitu sebesar 8,829 jelas jauh lebih tinggi dari angka tabel nya, sehingga angka tersebut tidak bisa di anggap kecil.Secara statistik telah membuktikan adanya pengaruh antara lingkungan sosial terhadap kualitas hidup penderita HIV/AIDS pada ibu rumah tangga sebesar 23,83\%.

Hasil penelitian, dapat dilihat bahwa variabel lingkungan sosial dalam memberikan dorongan kepada masyarakat tidak dipengaruhi oleh karakteristik responden, dalam hal ini meliputi pekerjaan, pendidikan, dan pekerjaan, tidak dipengaruhi oleh karakteristik responden karena hasil uji Chi Square dengan tingkat signifikansi $5 \%$ menunjukkan $\mathrm{P}$ value (Asymp. Sig) > 0,05 yang menunjukkan lingkungan sosial tidak dipengaruhi oleh karakteristik responden.

Hasil penelitian diperoleh bahwa lingkungan sosial berpengaruh positif terhadap kualitas hidup. Hasil uji terhadap koefisien parameter antara lingkungan sosial terhadap kualitas hidup menunjukkan ada pengaruh positif 0.547, sedangkan nilai T-Statistik sebesar 5.907 dan signifikan pada $\alpha=5 \%$. Nilai T-Statistik tersebut berada jauh diatas nilai kritis $(1,96)$.

Hasil ini membuktikan penelitian yang menyebutkan kemampuan seseorang dalam memelihara hubungan sosial (jaringan sosial) dan berpartisipasi dalam kegiatan sosial (aktivitas sosial). Jaringan sosial (social network) dinilai dari struktur dan kualitas hubungan interpersonal, sedangkan aktivitas sosial dicirikan dari partisipasi dalam aktivitas masyarakat yang bermakna dan produktif.

Lingkungan sosial mempunyai komponen jaringan sosial, yaitu kemampuan memelihara luasnya hubungan sosial dan aktivitas sosial, yaitu tingkat partisipasi dalam kegiatan dimasyarakat. Lebih banyak mempunyai aktivitas sosial dan lebih banyak mempunyai jaringan sosial diasosiasikan dengan lebih lambatnya penurunan kognitif dan mereka yang menerima dukungan emosional mempunyai kualitas hidup lebih baik (Rochmayanti, 2011).

Hasil ini juga mendukung penelitian yang dilakukan Budi Ryanto, di Jakarta barat bahwa ibu rumah tangga yang mengalami kongnisi buruk sebesar 37,8\% dan mengalami sosial engagement buruk sebesar $35,7 \%$ dari data diatas dapat disimpulkan bahwa ada pengaruh antara sosial engagement terhadap penurunan kogntif pada ibu rumah tangga (Purwaningsih, 2014).

http://jurnalilmiah.stikescitradelima.ac.id/index.php/JI Vol.4,No.1, Juli 2020 
Menurut asumsi peneliti bahwa ibu rumah tangga dengan HIV/AIDS yang berpartisipasi aktif dalam kegiatan sosial dan interaksi dengan orang lain, diketahui dapat membantu menstimulasi kualitas hidup dan memperlambat terjadinya kepikunan. Aktifitas sosial dan keterikatan sosial telah dibuktikan berpengaruh terhadap kualitas hidup pada ibu rumah tangga.

Lingkungan sosial mempunyai komponen jaringan sosial, yaitu kemampuan memelihara luasnya hubungan sosial dan aktivitas sosial, yaitu tingkat partisipasi dalam kegiatan dimasyarakat.

\section{Pengaruh Tidak Langsung Lingkungan Sosial terhadap Kualitas Hidup Melalui Peran Tenaga Kesehatan dan Peran Suami.}

Lingkungan sosial juga memiliki pengaruh tidak langsung terhadap kualitas hidupterhadap penderita HIV/AIDS pada ibu rumah tangga di Yayasan Pelita Ilmu Jakarta Selatan melalui peran tenaga kesehatan dan peran suami sebesar $0.359 \%$. Nilai T-Statistik sebesar 8.829 dan signifikan pada $\alpha=5 \%$. Nilai T-Statistik tersebut berada jauh diatas nilai kritis $(1,96)$.

Lingkungan sosial mempengaruhi kualitas hidupPenderita HIV/AIDS melalui peran tenaga kesehatan.Lingkungan sosial dan peran tenaga kesehatan merupakan satu kesatuan dalam kehidupan masyarakat.Peran tenaga kesehatan kepada masyarakat merupakan komponen yang sangat penting agar dapat menumbuhkan kepedulian terhadap bahaya HIV/AIDS.

Komunikasi yang efektif tentang pandangan bahaya HIV/AIDS dapat mengurangi keraguan masyarakat, menambah kunjungan ke fasilitas kesehatan, meningkatkan loyalitas masyarakat dan tumbuhnya praktik layanan petugas kesehatan.Pasien HIV/AIDS dan juga penyedia layanan kesehatan sama-sama mendapatkan bentuk manfaat dari keadaan yang saling berbagi dalam hubungan yang erat (Larasati, 2016).
Peran tenaga kesehatan adalah perilaku, tindakan dan penerimaan keluarga terhadap penderita yang sakit. Dukungan tenaga kesehatan sebagai suatu proses hubungan antara keluarga dengan lingkungan sosial. Ketiga dimensi interaksi dukungan sosial keluarga tersebut bersifat reprokasitas (sifat dan hubungan timbal balik), advis atau umpan balik(kuantitas dan kualitas komunikasi) dan keterlibatan emosional (kedalaman intimasi dan kepercayaan) dalam hubungan sosial (International HIV/AIDS Alliance, 2007).

Selain masalah fisik pasien HIV/AIDS juga menghadapi masalah sosial yang cukup memprihatinkan sebagai dampak dari adanya stigma terhadap penyakit ini.Jika tidak ada peran tenaga kesehatan yang memberikan penyuluhan tentang pencegahan HIV/AIDS dapat menyebabkan lingkungan sosial masyarakat menjadi tidak peduli terhadap bahaya HIV/ADIS.Hal ini disebabkan oleh karena penyakit ini identik dengan akibat dari perilaku-perilaku tidak bermoral seperti seks bebas, penyalahgunaan narkoba, dan sekssesama jenis (homoseksual) sehingga pasien dianggap pantas untuk mendapat hukuman akibat perbuatannya tersebut. Selain itu, stigma juga muncul karena pemahaman masyarakat yang kurang terhadap penyakit ini (Siregar, 2012).

Lingkungan sosial memberikan pengaruh tidak langsung terhadap peningkatan kualitas hidup seseorang melalui peran keluarga (suami).Keluarga (suami) sebagai sebuah tempat yang aman dan damai untuk istirahat dan pemulihan serta membantu penguasaan terhadap emosi penderita HIV/AIDS. Manfaat dari peran suami ini adalah secara emosional menjamin nilai-nilai individu (penderita HIV/AIDS) akan selalu terjagakerahasian dirinya dari keingintahuan orang lain. Aspek-aspek daridukungan emosional meliputi dukungan yang diwujudkan dalambentuk afeksi, adanya kepercayaan, perhatian dan mendengarkan sertadidengarkan. Ibu menyusui sangat membutuhkan keempat jenis dukunganyang berasal dari keluarga sehingga diharapkan

http://jurnalilmiah.stikescitradelima.ac.id/index.php/JI Vol.4,No.1, Juli 2020 
dapat mempercepat prosespenyembuhan terhadap penyakit HIV/AIDS (Gilbert, 2010).

\section{Pengaruh Langsung Peran Tenaga Kesehatan terhadap Kualitas Hidup.}

Pengaruh langsung dan besaran peran tenaga kesehatan terhadap kualitas hidu penderita HIV/AIDS pada ibu rumah tangga di Yayasan Pelita Ilmu tahun 2017 adalah sebesar sebesar 30,31\%. Sedangkan nilai Tstatistik sebesar 2,185dan signifikan pada alpha 5\%. Nilai T Statistik tersebut berada di atas nilai kritis $(1,96)$.

Hasil penelitian, dapat dilihat bahwa variabel peran tenaga kesehatan dalam memberikan dorongan kepada masyarakat tidak dipengaruhi oleh karakteristik responden, dalam hal ini meliputi Pekerjaan, pendidikan, dan pekerjaan, tidak dipengaruhi oleh karakteristik responden karena hasil uji Chi Square dengan tingkat signifikansi 5\% menunjukkan $\mathrm{P}$ value (Asymp.Sig) > 0,05 yang menunjukkan peran tenaga kesehatan tidak dipengaruhi oleh karakteristik responden.

Hasil penelitian diperkuat bahwa bentuk peran tenaga kesehatan merupakan penyediaan materi yang dapat memberikan bantuan langsung seperti pemberian uang, pemberian barang, makanan serta pelayanan.Bentuk ini dapat mengurangi sikap negatifmasyarakat karena individu dapat langsung memecahkan masalahnya yang behubungan dengan materi.Dukungan instrumental sangat diperlukan terutama dalam mengatasi masalah yang dianggap dapat dikontrol (Ermarfini, 2012).

Hasil penelitian ini juga didukung ada hubungan yang positif peran petugas kesehatan dengan kualitas hidup penderita HIV/AIDS pada ibu rumah tangga dengan nilai probabilitas sebesar 0,001. Hasil Penelitian menunjukan bahwa peran tenaga kesehatan antara lain memperkenalkan kepada masyarakat gagasan dan teknik merawat ibu rumah tangga, yang merupakan pendekatan terencana untuk mencegah penyakit masyarakat secara meluas. Tenaga kesehatan dapat bekerjasama dengan pihak yang terlibat seperti tokoh masyarakat dan masyarakat peduli ibu rumah tanggamelalui pesan-pesan sederhana, positif, menarik yang dirancang untuk dikomunikasikan lewat sarana lokal seperti poster, leaflet tentang peningkatan fungsi ibu rumah tangga (Ermarfini, 2012).

Menurut asumsi peneliti peran tenaga kesehatan merupakan bantuan atau dukungan yang diterima masyarakat dari petugas kesehatan dalam mendorong kepatuhan ibu rumah tangga dalam meningkatkan kualitas hidup. Diharapkan dengan adanya dukungan dari petugas kesehatan maka masyarakat akan merasa diperhatikan, dihargai dan dicintai. Dengan pemberian dukungan yang bermakna maka masyarakat akan mengatasi rasa cemasnya terhadap persoalan ibu rumah tangga.

\section{Pengaruh Tidak Langsung Peran Tenaga Kesehatan terhadap Kualitas Hidup Melalui Peran Suami.}

Peran tenaga kesehatan mempengaruhi kualitas hidup seseorang melalui peran suami sebesar $0.013 \%$. Nilai T-Statistik sebesar 2.185 dan signifikan pada $\alpha=5 \%$. Nilai T-Statistik tersebut berada jauh diatas nilai kritis $(1,96)$.

Hasil uji tersebut dapat dijelaskan bahwa pengaruh tidak langsung tenaga kesehatan terhadap kualitas hidup penderita HIV/AIDS pada ibu rumah tangga di Yayasan Pelita Ilmu Jakarta Selatan dilalui oleh variabel peran suami sebesar $0.132 \%$.

Peran tenaga kesehatan memiliki hubungan yang kuat dengan kualitas hidup seseorang melalui peran keluarga (suami).Peran suami untuk menyadari bahwa untuk meningkatkan derajat kesehatan perempuan dengan rutin memeriksakan kesehatannya, hal ini dapat menimbulkan perilaku positif seseorang tentang pentingnya kesehatan, sehingga seseorang bersedia

http://jurnalilmiah.stikescitradelima.ac.id/index.php/JI Vol.4,No.1, Juli 2020 
untuk melakukan pemeriksaan terkait dengan kesehatannya (Fitriani, 2012).

Peran tenaga kesehatan memiliki pengaruh tidak langsung terhadap peran suami dalam melakukan sosialisasi tes HIV-AIDS bagi ibu rumah tangga yang mempunyai faktor resiko tersebut sangat penting untuk menurunkan bahkan mencegah kejadian penularan HIVAIDS dari ibu hamil kepada janinnya yang disebut sebagai pelayanan pemeriksaan HIV/AIDS.Mengingat peran tenaga kesehatan yang merupakan ujung tombak dalam pelayanan ANC khususnya pada ibu rumah tangga dengan HIV/AIDS yang mempunyai faktor resiko tertular HIV-AIDS, maka sosialisasi pencegahan HIV/AIDS harus tetap dilaksanakan (Fitriani, 2012).

Hasil penelitian ini didukung ada hubungan antara peran suami dengan kualitas hidup ibu rumah tangga dengan HIV/AIDS dalam mencegah penularan HIVAIDS di Station Bengkayang Singkawang Kabupaten Sambas Provinsi Kalimantan Barat, menunjukkan bahwa $66,6 \%$ memiliki peran suami yang baik dan mendukung istri mengikuti pengobatan (Aryanti, 2013).

\section{Pengaruh Langsung Peran Suami Terhadap Kualitas Hidup.}

Pengaruh langsung dan besaran peran suami meterhadap kualitas hidup penderita HIV/AIDS pada ibu rumah tangga di Yayasan Pelita Ilmu tahun 2017 adalah sebesar sebesar 10,5\%. variabel Peran suami tidak dipengaruhi oleh karakteristik responden, dalam hal ini meliputi Pekerjaan, pendidikan, dan pekerjaan, tidak dipengaruhi oleh karakteristik responden karena hasil uji Chi Square dengan tingkat signifikansi 5\% menunjukkan $\mathrm{P}$ value (Asymp.Sig) > 0,05 yang menunjukkan peran Peran suami tidak dipengaruhi oleh karakteristik responden.

Hasil uji terhadap koefisien parameter antara Peran suami terhadap kualitas hidup penderita HIV/AIDS pada ibu rumah tanggamenunjukan nilai $\mathrm{T}$ satistik diperoleh 7.915, maka nilai t lebih besar dari t tabel yaitu $5 \%$ atau nilai $\mathrm{t}<1,96$ berarti terdapat pengaruh positif peran suami terhadap kualitas hidup penderita HIV/AIDS pada ibu rumah tangga.Peran suami merupakan bentuk kepedulian dari anggota keluarga baik secara emosi maupun materi yang diwujudkan dalam bentuk informasi, perhatian dan bantuan yang dapat mempengaruhi kualitas hidup penderita HIV/AIDS pada ibu rumah tangga.

Hasil penelitian ini didukung oleh penelitian sebelumnya dimana a) informasi yang diberikan oleh keluarga mampu membantu ibu rumah tangga untuk menghadapi suatu permasalahan dan mencari solusi atas permasalahan yang dihadapi, infomasi itu juga dapat menyumbangkan aksi sugesti yang khusus pada setiap individu, berupa usuran, saran, pengarahan atau petunjuk, serta umpan balik tentang apa dan bagaimana seseorang harus bersikap dalam menghadapi masalah yang sering di hadapi ibu rumah tangga, b) perhatian yang diberikan oleh keluarga terbukti dapat membantu ibu rumah tangga untuk menjalankan hari - harinya dengan baik, dengan adanya perhatian dari orang - orang terdekat mampu membangkitkan semangat ibu rumah tangga untuk menjalankan tugas dan fungsinya sebagai mana mestinya, keluarga merupakan tempat yang aman dan damai untuk istrirahat dan pemulihan. Keluarga merupakan wadah untuk mencurahkan kegelisahan, mendengarkan dan didengarkan, pemberian semangat, kehangatan, cinta kasih adalah modal utama yang dibutuhkan ibu rumah tangga untuk menjalankan hari harinya agar lebih berkualitas khususnya dalam mempertahankan kualitas hidupnya, c) bantuan yang diberikan secara langsung baik yang bersifat fasiliatis ataupun materi juga sangat diperlukan ibu rumah tangga, perasaan tidak diacuhkan dari orang - orang terdekat dapat membuat ibu rumah tangga mempertahankan Kualitas Hidupnya (Fitria, 2016).

Hasil penelitian ini didukung oleh penelitian sebelumnya tentang pengaruh Peran suami terhadap kualitas hidup penderita HIV/AIDS pada ibu rumah

http://jurnalilmiah.stikescitradelima.ac.id/index.php/JI Vol.4,No.1, Juli 2020 
tanggamenyatakan bahwa peran keluarga sangat mempengaruhi terhadap status kesehatan ibu rumah tangga,jika peran keluarga itu baik maka diharapkan status kesehatan ibu rumah tangga juga baik dan sebaliknya jika peran keluarga kurang, maka status kesehatan pada ibu rumah tangga juga buruk (Nicke, 2015).

Menurut asumsi penulis dukungan yang diberikan keluarga dimana pada awalnya keluarga berfungsi sebagai sebuah disseminator (penyebar) informasi tentang lingkungannya. Ibu rumah tangga yang ,menderita HIV/AIDS bukan hanya dapat merugikan diri sendiri, tetapi akan berdampak bagi keluarga yang merawat ibu rumah tangga yang menderita HIV/AIDS. selain terbeban secara fisik karena harus merawat, mengawasi, dan memperhatikan segala kebutuhan ibu rumah tangga juga terbeban secara emosional, dimana ibu rumah tangga yang mengalami HIV/AIDS akan bertingkah laku semaunya saja dan ini dapat menimbulkan penyakit baru bagi keluarga, yang terkadang harus mengendalikan emosinya. Apabila individu tidak dapat menyelesaikan masalah yang dihadapi maka dukungan ini diberikan dengan cara memberi informasi, nasehat, dan petunjuk tentang cara penyelesaian masalah (Kemenkes RI, 2015).

\section{SIMPULAN}

Berdasarkan dari temuan penelitian didapatkan peran tenaga kesehatan merupakan faktor yang dominan yang sangat mempengaruhi kualitas hidup penderita HIV/AIDS pada ibu rumah tangga. Semakin tinggi peran tenaga kesehatan maka semakin baikkualitas hidup penderita hiv/aids pada ibu rumah tanggadan sebaliknya semakin rendah peran tenaga kesehatan maka semakin burukkualitas hidup penderita HIV/AIDS pada ibu rumah tanggadi Wilayah Kerja Yayasan Pelita Ilmu Jakarta Selatan.

\section{DAFTAR PUSTAKA}

Aryanti, Wardiyah. (2013). Faktor-Faktor yang Mempengaruhi Kualitas Hidup terhadap Kesembuhan pada Pasien Kanker Payudara di RSUPN Dr. Cipto Mangunkusumo Jakarta. Tesis. Depok: Fakultas Ilmu Keperawatan Pogram Universitas Indonesia.

Aritonang A N, dkk. (2014). Konsep Diri Orang HIV/AIDS (ODHA). Jurnal. Bandung: Sekolah Tinggi Ilmu Kesejahteraan Sosial (STKS).

Dewi I S, Fuziah N. (2016). Sebuah Studi Fenomenologi Kehidupan Orang Dengan HIV/AIDS. Jurnal. Semarang: Fakultas Psikologi Universitas Diponegoro.

Ermarfini, Anggia. (2012). Faktor-Faktor yang Berhubungan dengan Pemanfaatan Layanan VCT pada Populasi Beresiko Tinggi HIV/AIDS di Provinsi Banten Depok: Tesis.Magister Fakultas Kesehatan Masyarakat Univeristas Indonesia.

Fitria Y. (2016). Analisis Korelasi Penerimaan Harga Diri Orang Tua dan Stress Pengasuhan dalam Merawat Anak Retardasi Mental. Jurnal. Malang: Fakultas Kedokteran Universitas Brawijaya Program Studi Magister Keperawatan, Vol.2 No.4 hlm. 276284

Fitriani, S. (2012). Promosi Kesehatan. Yogyakarta: Graha Ilmu.

Gilbert, L., Walker, L. (2010). My Biggest Fear was that People Would Reject Me once they Knew My Status... ':Stigma as Experienced by Patients in an HIV/AIDS Clinic in Johannesburg,South Africa. Journal Health and Social Care in the Community. Vol.18. No.2. 139-146.

Ghozali. (2008). Structural Equation Modeling Metode Alternatif dengan Partial Least Square (PLS), Semarang : UNDIP.

Haruddin,dkk. (2010). Studi Pelaksanaan HIV Voluntary Counseling and Testing (VCT) di RSUP DR. Sarjito Yogyakarta http//irc.kmpk.ugm.ac.id. http://jurnalilmiah.stikescitradelima.ac.id/index.php/JI Vol.4,No.1, Juli 2020 
Hena Khan. (2015). Effect of Resilience and Social Support on Immune Activation in HIV Positive People. Journal of Indian Psychology Vol.2

International HIV/AIDS Alliance. (2007). Positive Prevention. HIV Prevention with People Living with HIV. A Guide for NGOs and Service Providers. UK: International HIV/AIDS Alliance. Kementrian Kesehatan RI. (2015). Konseling dan Tes HIV atas Inisiasi Petugas Kesehatan. Direktorat Jendral Pengendalian Penyakit dan Penyehatan Lingkungan.

Larasati. (2016). Kualitas Hidup Wanita Menopause. Diambil tanggal 22 Desmebr 2016

Mustafa Z MQ \& Tony W. (2012). Panduan Teknik Statistik SEM \& PLS dengan SPSS AMOS.

Nazir, K. (2010). Penilaian Kualitas Hidup Pasien Pasca Bedah Pintas Koroner yang Menjalani Rehabilitasi Fase III dengan Menggunakan SF36,. Jakarta: Universitas Indonesia.

Nicke P. (2015). Resiliensi Penderita HIV Positif ditinjau dari Relasi dalam Keluarga. Jurnal. Malang: Fakultas Psikologi Universitas Merdeka Malang.

Nursalam. (2011). Konsep dan Penerapan Metodologi Penelitian Keperawatan. Jakarta: Salemba Medika.

Purwaningsih. (2014). Analisis Faktor Pemanfaatan VCT pada Orang Risiko Tinggi HIV/AIDS di Puskesmas Dupak, Surabaya. Tesis. Unair.

Rochmayanti. (2011). Analisis Faktor-Faktor yang Mempengaruhi Kualitas Hidup Pasien Penyakit Jantung Koroner di Rumah Sakit Pelni Jakarta. Tesis, Universitas Indonesia.

Rulianthina, Pramadita. (2008). Strategi Adaptasi Psikososial dan Ekonomi pada Keluarga ODHA karena Penggunaan Narkoba dengan Jarum Suntik (Studi Keluarga dan Anak-anak Rawan
HIV dan AIDS. Skripsi. Fakultas Kesehatan Masyarakat Universitas Indonesia.

Saptari, Adila Fahmida. (2013). Hubungan Sikap dan Pengetahuam dengan Niat Mendukung Praktikan Pemberianb ASI Ekslusif pada Mahasiswa Magister Pria Universitas Indonesia. Depok : Skripsi. Fakultas Kesehatan Masyarakat Universita Indonesia.

Siregar, Nurlama. (2012). Pengaruh Stigma Orang dengan HIV-AIDS (ODHA) terhadap Penerimaan Masyarakat Desa Buntu Bedimbar di Kecamatan Tanjung Morawa Kabupaten Deli Serdang. Tesis. Fakultas Kesehatan Masyarakat Universitas Sumatera Utara.

Widyaningtyas N. (2009). Studi Deskriptif tentang Derajat Resiliensi pada Wanita HIV/AIDS di Sanggar Kerja Yayasan " $X$ ” Jakarta. Skripsi. Jakarta : Universitas Kristen Maranath.

World Health Organization. (2010). PMTCT Strategic Vision 2010-2015: Preventing mother- to-child transmission of HIV to reach the UNGASS and Millennium Development Goals.

Yayasan Pelita Ilmu Jakarta. (2016). Jumlah HIV/AIDS Kategori Penularan Di Wilayah Jakarta Selatan. Jakarta.

http://jurnalilmiah.stikescitradelima.ac.id/index.php/JI Vol.4,No.1, Juli 2020 